\title{
SEEKING THE COMMON GOOD OR Just MAKING US BE GOOD? RECENT AMENDMENT TO NEW ZEALAND'S SOCIAL SECURITY LAW
}

\author{
Māmari Stephens*
}

\begin{abstract}
New Zealand's social security system was born out of a vision of society consistent with a definition of the common good informed by Christian ethics. The past 30 years, in particular, have seen fierce ideological battles fought between the left and right over the extent, coverage, and generosity of the system. Yet a remnant of the vision of the common good remains, whereby individuals can have some access, by virtue of social security, to the sufficient conditions of social life to be free enough to find some level of fulfilment in that life. However, the freedom to be good, as is also required by a broad understanding of the common good, is under threat within New Zealand's social security law. Social security law asserts a vision, and not a coherent one, of what it means to be good in New Zealand society. Newly minted social obligations in the Social Security Act 1964 go beyond the purposes of the legislation; being unconnected to relieving need, maintaining fiscal prudence, or even seeking paid employment as a means of achieving welfare. These modern moral obligations ensure that beneficiaries' freedom to choose to live life in a way consonant with the common good is frustrated, if not substantially abrogated, striking the wrong balance between the law's protection of individual autonomy and its implementation of social imperatives in pursuit of the common good.
\end{abstract}

\section{INTRODUCTION}

In 1965 the Second Vatican Council issued a highly influential observation about the "common good"- calling on the teachings of Aristotle and Aquinas, among others: ${ }^{1}$

Every day human interdependence grows more tightly drawn and spreads by degrees over the whole world. As a result the common good, that is, the sum of those conditions of social life which allow social

* Senior Lecturer in Law, Faculty of Law, Victoria University of Wellington.

1 Second Vatican Council "Pastoral Constitution on the Church in the Modern World - Gaudium et Spes" (7 December 1965) [Gaudium et Spes] (emphasis added). See also Mary M Keys Aquinas, Aristotle and the Promise of the Common Good (Cambridge University Press, New York, 2006). 
groups and their individual members relatively thorough and ready access to their own fulfillment, today takes on an increasingly universal complexion and consequently involves rights and duties with respect to the whole human race. Every social group must take account of the needs and legitimate aspiration of other groups, and even of the general welfare of the entire human family.

This definition of the common good identifies (without defining) a set of conditions that enables individuals and groups in society to have the kind of social life that enables them to seek and achieve fulfilment. Making such conditions of social life accessible cannot be achieved by individuals alone, and requires some degree of institutional involvement.

Importantly, this definition appears to presume the existence of agency; the conditions of social life are such that they allow individuals and groups to have access to their own fulfilment. This tone presupposes that such individuals and groups might choose not to access such fulfilment. This notion of agency, and of the primacy of the individual appears more explicitly in the paragraph immediately after the definition, albeit in gendered language: ${ }^{2}$

At the same time, however, there is a growing awareness of the exalted dignity proper to the human person, since he stands above all things, and his rights and duties are universal and inviolable. Therefore, there must be made available to all men everything necessary for leading a life truly human, such as food, clothing, and shelter; the right to choose a state of life freely and to found a family, the right to education, to employment, to a good reputation, to respect, to appropriate information, to activity in accord with the upright norm of one's own conscience, to protection of privacy and rightful freedom even in matters religious.

The common good then, on this reading, encompasses two closely related notions of freedom. The first refers to the importance of having sufficient access to those conditions of social life to be free enough to live such a life. Roosevelt called this, in his famous Four Freedoms speech to Congress, "freedom from want". ${ }^{3}$ Indeed this freedom was articulated in the preamble of the Universal Declaration of Human Rights: ${ }^{4}$

Whereas disregard and contempt for human rights have resulted in barbarous acts which have outraged the conscience of mankind, and the advent of a world in which human beings shall enjoy freedom of speech and belief and freedom from fear and want has been proclaimed the highest aspiration of the common people ...

2 Gaudium et Spes, above n 1, at [26].

3 Franklin D Roosevelt, President of the United States of America "Message to Congress" (6 January 1941).

4 Universal Declaration of Human Rights GA res 217A, III A/810 (1948). 
But in addition, individuals (and groups) must have the freedom to choose to live the social life that in turn benefits others to the good of the whole. The common good, then, requires that individuals and groups in society have the freedom to be, and the freedom to be good.

The role of the law in both promoting and protecting these freedoms to live a life compatible with the common good is therefore worthy of some consideration. One topic where the notion of the common good and the role of law in achieving it are most disputed internationally, as well as domestically, is the law of welfare, or social security. On the one hand social security law creates a set of statutory entitlements for those individuals who are unable to support themselves fully, and who suffer some level of income deprivation. This support is intended to provide its recipients with the means to survive and participate within society - the freedom to be. However, the law of social security also upholds social norms, and increasingly in many Western countries, imposes positive obligations upon social security recipients that require them to demonstrate certain kinds of good behaviour in order to be eligible for support. ${ }^{5}$ These requirements affect such recipients' freedom to choose to be good.

New Zealand's own social security was also born out of a vision of society that is consistent with the definition of the common good employed in this article. The birth of New Zealand social security in its consolidated and systemised form in 1938 was the product of an ideological vision, informed, to some degree, by Christian ethics. When Michael Joseph Savage was challenged in the Parliamentary debates on the 1938 Social Security Bill with the accusation that the proposed scheme was so generous as to be "applied lunacy", Savage retorted that to his mind it was "applied Christianity". ${ }^{6}$ Those ethics also served a particular political stance concerning the redistribution of wealth in society. Walter Nash, the first Minister of Social Security believed that the First Labour Government had put into action the principle "that the care of the aged and the care of the young should be the first charge on all wealth creating." 7

The decades since 1938, particularly since the mid-1970s, have seen little subsequent agreement about what comprises poverty. Similarly, there is also little agreement as to what constitutes

5 See for example Peter Dwyer "Creeping Conditionality in the UK: From Welfare Rights to Conditional Entitlements?" (2004) 29 Canadian Journal of Sociology 265-287; and Nicola Barker and Sarah Lamble "From Social Security to Individual Responsibility: Sanctions, Conditionality and Punitiveness in the Welfare Reform Bill 2009 (Part One)" (2009) 31 Journal of Social Welfare and Family Law 321.

6 Michael Bassett "How Ideal was the Savage Ideal" MJ Savage Memorial Lecture, La Trobe University (4 September 1998) <http://www.michaelbassett.co.nz/article_savage.htm>.

7 Upper Hutt Leader "Mr Nash Addresses Electors at Upper Hutt", (10 November 1949) Upper Hutt City Library $<$ http://newspaperarchives.uhcc.govt.nz/>. 
appropriate welfare, or the "good life and [the] just society" from which those in poverty are excluded, notwithstanding the convictions of the architects of the system. ${ }^{8}$

Nevertheless the fact that the system of social security that we now have is still recognisable as a product of that early vision is testament to a limited agreement between all the governments since the 1930s of the ongoing need for the State provision of a needs-based, residual welfare system to allow those in poverty to be financially sustained in a fiscally responsible manner, and for those recipients to have a degree of participation in society from which they would otherwise be excluded. The past 30 years, in particular, have seen fierce ideological battles fought between the left and right over the extent, coverage, and generosity of the system, yet it remains. For as long as it does, a remnant of the vision of the common good somehow also survives, whereby individuals can have some access, by virtue of social security, to the sufficient conditions of social life to be free enough to find some level of fulfilment in that life. The true extent of this first kind of freedom to have access to sufficient assistance under successive governments has been subject to extensive critique, but is not the primary focus of this article. ${ }^{9}$

Instead, the focus is on the freedom to be good, as is also required for the common good, and this freedom is certainly at issue within the context of New Zealand's social security law. More so than perhaps most other bodies of law, social security law asserts a vision, and not a coherent one, of what it means to be good in New Zealand society, on the presumption that certain kinds of behaviour are better than others and ought to be promoted and upheld within social security law.

The newly minted social obligations established under ss 60RA-60RC of the Social Security Act 1964 provide direction to beneficiary parents of dependent children on how to be good, punishing

8 For difficulties in defining poverty see Frances Stewart, Ruhi Saith, and Caterina Ruggeri Laderchi "Introduction: four approaches to defining and measuring poverty" in Frances Stewart and others Defining Poverty in the Developing World (Palgrave Macmillan, New York, 2007) at 27. New Zealand is reluctant to operate a formal definition of poverty, a position reflected internationally in social security legislation. One exception is in the Child Poverty Act 2010 (UK), an Act which does not concern social security, but sets up a system to monitor child poverty in the United Kingdom. For recent statistics on relative poverty and inequality using informal measures such as the Gini Coefficient and absolute and relative poverty lines see Bryan Perry Household incomes in New Zealand: Trends in indicators of inequality and hardship 19822011 (Ministry of Social Development, August 2012).

9 For such critique and debate, particularly with regards to recent reforms, see Welfare Working Group LongTerm Benefit Dependency: Recommendations (Welfare Working Group, February 2011); Welfare Justice (Alternative Welfare Working Group) Welfare Justice in New Zealand: Welfare Justice for All (Caritas, December 2010); Tony McGurk The Unravelling of the Welfare Safety Net (Beneficiary Advocacy Federation of New Zealand and Caritas Aotearoa New Zealand, September 2008); Welfare Justice (Alternative Welfare Working Group) Welfare Justice in New Zealand: What We Heard (Caritas, November 2010); Matthew Hodgson and Mike O'Brien Child Poverty and Child Well-Being: New Zealand in an International Context (Child Poverty Action Group, Auckland, July 2010); Susan St John and Keith Rankin Escaping the Welfare Mess? (Child Poverty Action Group, Auckland, Working Paper Series No 267, December 2009). 
failure with sanctions in the form of cutting or suspending benefit payments. The obligations are not relevant to either relieving need or the maintenance of fiscal prudence, or even the focus of seeking paid employment as a means of achieving welfare.

The fact that these obligations are highly directive and unconnected to the purposes of social security makes these obligations difficult to justify in a modern legislative scheme, comprising an effective level of morals testing more directive (in the legislation) than that included in the Old Age Pension Act of 1898, and the subsequent Social Security Act 1938. These modern moral obligations ensure that beneficiaries' freedom to choose to live life in a way consonant with the common good is frustrated, if not substantially abrogated, striking the wrong balance between the law's protection of individual autonomy and its implementation of social imperatives in pursuit of the common good.

\section{LAW, FREEDOM, AND THE COMMON GOOD}

There are at least three ways law can encourage or enable us to lead good lives consistent with the common good. These three aspects of law must be held in balance if the autonomy of the individual is to be protected from the coercive power of the State.

\section{A Pointing to the Good Life by Punishing Bad Actions}

Law can suggest what the content of the good life might mean by penalising the activities of the bad life. Perhaps in criminal law this characteristic is most obvious. We live a good life if we do not murder, if we do not steal, if we do not cheat others. Most often the law does this by sanctioning or penalising actions that involve harming others. ${ }^{10}$ The autonomous individual at the heart of our Western legal system ought not have her autonomy removed, but by having sanctions in place for certain kinds of behaviour the system nudges that individual to the right kind of life. ${ }^{11}$ As Paul said in Romans $7: 7:^{12}$

What shall we say, then? Is the law sinful? Certainly not! Nevertheless, I would not have known what sin was had it not been for the law. For I would not have known what coveting really was if the law had not said, 'You shall not covet.'

10 For the basis of modern discussion of the harm principle see J S Mill On Liberty (Longman, Roberts \& Green, London, 1859). See also Joel Feinberg Harm to Others: The Moral Limits of the Criminal Law (Oxford University Press, New York, 1984).

11 Regarding the primacy of the autonomous individual at the heart of the criminal law, see, among others, Andrew Ashworth Principles of Criminal Law (6th ed, Oxford University Press, Oxford, 2009) at 52-83. This is not to say that there is no place for the criminally responsible collective or corporate identity or entity in the criminal law, only that criminal fault is far more often, and more easily, attributable to individuals rather than collectives.

12 New International Version (NIV). 
The fact that the harshest of criminal penalties are reserved for morally blameworthy actions when done with morally blameworthy thoughts might enable us more clearly to see what morally praiseworthy conduct might be. Nevertheless such law usually only points us in such a direction.

\section{$B$ Pointing to the Good Life by Imposing Positive Obligations in Law}

Sometimes the law does impose more direct obligations on us to behave in good ways, creating standards of behaviour, the breach of which can be penalised. Generally speaking, this function is less the province of the criminal law; although there is a handful of duties in the criminal law, the breach of which are criminalised and punished. ${ }^{13}$ The criminal law usually falls shy of directing us to be good except in certain circumstances. Generally speaking we are not obliged to be good Samaritans. For example, the universal moral obligation to love our neighbour did not make it into the Crimes Act $1961 .^{14}$

Nevertheless in other areas of law we can find ourselves under obligation to fulfil a standard of care in our private law dealings with others, as the much watered-down Good Samaritan neighbour principle demonstrates in the very practical world of tort law. ${ }^{15}$ Breach that duty (and standard) of care, and cause damage to the interests of someone close enough to you, and you may be penalised. Positive obligations are also increasingly imposed upon individuals in many different forms by legislation and regulation, and indeed, obligation, even obligations to social institutions, is a necessary condition of achieving the common good: ${ }^{16}$

It grows increasingly true that the obligations of justice and love are fulfilled only if each person, contributing to the common good, according to his own abilities and the needs of others also promotes and assists the public and private institutions dedicated to bettering the conditions of human life.

For such "public institutions" that better "the conditions of human life" to require individuals to act, and sanctioning them when they fail to act, necessarily restricts the freedom of those individuals. Such restriction must be justified, and thus be relevant to the purposes of such institutions.

13 See for example, Crimes Act 1961, ss 150A-157 and ss 195-195A for codified duties. Common law duties may also be applicable that are not covered by the statute, for example when a defendant has created the situation that produces the relevant harm, as discussed in the case of $R v$ Miller [1983] 2 AC 161 (HL).

14 Christopher D Marshall Compassionate Justice: An Interdisciplinary Dialogue with Two Gospel Parables on Law, Crime, and Restorative Justice (Cascade Books, Eugene (Oregon), 2012) at 34.

15 Donoghue v Stevenson [1932] AC 562 at 580 (HL) per Lord Atkin: "But acts or omissions which any moral code would censure cannot in a practical world be treated so as to give a right to every person injured by them to demand relief. In this way rules of law arise which limit the range of complainants and the extent of their remedy. The rule that you are to love your neighbour becomes in law, you must not injure your neighbour; and the lawyer's question, Who is my neighbour? receives a restricted reply."

16 Gaudium et Spes, above n 1, at [30]. 


\section{Protection of Freedom}

The use of law to impose penalties for bad behaviour as well as for enforcing positive obligations creates tensions with the third function of law that is important for the creation and protection of the common good. That function is to create space and freedom for autonomous individuals to choose to live a good social life. Creating that freedom comes about by ensuring, for example, autonomy, as far as is practicable, is protected, and that rights accruing to such individuals are protected, or at least only breached under certain defined and limited circumstances. Further, laws must be effective, not oppressive, and reach everybody; they must be accessible, and reasonable. The role law can play in pointing out the righteous and good life by the penalising of bad actions and the imposition of positive obligations must always then, in this Western legal framework, be held in balance by the preservation of individual freedom if such laws are not to become oppressive.

All three aspects or functions of law appear in social security law, but arguably the balance between these aspects has, in recent developments, been distorted.

\section{SANCTION AND OBLIGATION IN SOCIAL SECURITY LAW}

In order to ascertain how the balance between these three aspects has changed to the detriment of individual freedom in social security law it is necessary to identify who resides at the heart of social security law, and the overriding purposes of the Social Security Act 1964, as underpinning "an institution dedicated to bettering the conditions of human life."

\section{A The Individual at the Heart of Social Security}

As with other countries implementing formal social security (as opposed to informal social security relying on kin-based or charitable aid) the New Zealand social security system, in common with other industrialised nations, created an individualised system of entitlements. ${ }^{17}$ In this system the State stood in for the (typically male) wage-earning labourer who, by reason of unfortunate social contingency, had been excluded from working. ${ }^{18}$ If a man lost his job State-provided income replacement could ensure that the worker and his family could at least survive at a very basic level,

17 For reflection on the extent to which Māori modes of welfare have been excluded from the concepts underpinning New Zealand social security, see Margaret Tennant The Fabric of Welfare - Voluntary Organisations in Government and Welfare in New Zealand, 1840-2005 (Bridget Williams Books, Wellington, 2007) at 18; Margaret McClure A civilised community: a history of social security in New Zealand 1898-1998 (Auckland University Press in association with the Historical branch, Department of Internal Affairs, Auckland, 1998) at 111-124. See also Māmari Stephens "The Whānau Ora Approach" in M Claire Dale, Mike O'Brien and Susan St John (eds) Left Further Behind: how policies fail the poorest children in New Zealand (Child Poverty Action Group, Auckland, 2011) at 33-44.

18 See Māmari Stephens "The Right to Social Security in New Zealand" in Margaret Bedggood and Kris Gledhill Law into Action: Implementing Economic Social and Cultural Rights in Aotearoa New Zealand (Human Rights Foundation, Wellington, 2011) at 132. 
and the worker could eventually be returned to economic productivity. If a woman was widowed or deserted by her spouse, the State could then step into the shoes of the absent male wage labourer, thereby ensuring that the family could survive and eventually return to economic productivity once the needs of the children no longer required full time care. Such social investment would prove less costly to the State than the costs that might be incurred if families were allowed to break down entirely by being forced into reliance on charity or family members.

\section{B The purposes of the Social Security Act 1964}

The starting point for identifying the purposes of the Social Security Act 1964 is, in fact, the still-extant Long Title of the 1938 Act: ${ }^{19}$

An Act to provide for the Payment of Superannuation Benefits and of other Benefits destined to safeguard the People of New Zealand from Disabilities arising from Age, Sickness, Widowhood, Orphanhood, Unemployment, or other Exceptional Conditions; ... to provide such other benefits as may be necessary to maintain and promote the Health and General Welfare of the Community.

Clearly reflecting an understanding of the common good as discussed in the introduction, this Long Title served as the only statement of purpose in social security for many decades. In the 1990s the courts further elucidated the purposes of the legislation. The Court of Appeal stated in Rukav Department of Social Welfare that "[t]he concern of the legislation is with the provision of financial help for people who for one reason or another could not be expected to support themselves". ${ }^{20} \mathrm{~A}$ few years later the High Court also referred to the Act's twin purposes: to provide social security to those in need but in a fiscally responsible manner: ${ }^{21}$

The concern and purpose of the Act is to aid those who truly are in need of financial assistance in a way that is administratively efficient and not wasteful of public funds. Those considerations have to be balanced ...

In 2007 a new purposes section (s 1A) was inserted into the Act. ${ }^{22}$ The text is worth setting out in full: $:^{23}$

Purpose The purpose of this Act is-

(a) to enable the provision of financial and other support as appropriate-

19 Emphasis added.

20 Ruka v Department of Social Welfare [1997] 1 NZLR 154 at 161 (CA) per Richardson P.

21 Chief Executive of the Department of Work and Income v Vicary [2001] NZAR 628 (HC).

22 Section 1A was inserted by s 23 Social Security Amendment Act 2007.

23 Section 1A(d) was inserted by Social Security (Benefit Categories and Work Focus) Amendment Act 2013, s 5 . 
(i) to help people to support themselves and their dependants while not in paid employment; and

(ii) to help people to find or retain paid employment; and

(iii) to help people for whom work may not currently be appropriate because of sickness, injury, disability, or caring responsibilities, to support themselves and their dependants:

(b) to enable in certain circumstances the provision of financial support to people to help alleviate hardship:

(c) to ensure that the financial support referred to in paragraphs (a) and (b) is provided to people taking into account-

(i) that where appropriate they should use the resources available to them before seeking financial support under this Act; and

(ii) any financial support that they are eligible for or already receive, otherwise than under this Act, from publicly funded sources:

(ca) to provide services to encourage and help young persons to move to education, training, and employment rather than to receiving financial support under this Act:

[(d) to impose, on the following specified people or young persons, the following specified requirements or obligations:

(i) on people seeking or receiving financial support under this Act, administrative and, where appropriate, work-related requirements; and

(ii) on young persons who are seeking or receiving financial support under this Act, educational, budget management, and (where appropriate) parenting requirements; and

(iii) on people receiving certain financial support under this Act, social obligations relating to the education and primary health care of their dependent children.]

The Hon David Benson-Pope (Minister for Social Development and Employment) then noted the intent to maintain consistency between the purposes as outlined in the Long Title, case law and $\mathrm{s}$ 1A when introducing the First Reading of the Bill. ${ }^{24}$

In addition, for the first time the bill introduces purpose and principles provisions into the Social Security Act. Some of these statements are new; others are based on existing case law. They are

24 (8 May 2007) 639 NZPD 8966. 
intended to make the law easier to understand and much more accessible. Certainly there is no intent to

undermine the purposes set out in the long title of the 1938 Act.

The High Court has indeed recently interpreted s $1 \mathrm{~A}$ as being broadly consistent with the earlier case law, noting that the earlier decision of Ruka was reflected in $\mathrm{s} 1 \mathrm{~A} .{ }^{25}$

Section 1A(a)-(ca) establishes that the "provision of financial and other support" provided under the Act are to be seen as the means to effect a number of ends consistent with the overall purposes of the legislation, as noted above, including:

- Recipients being able to support themselves and their families, taking account of monies from other sources;

- the re-entry of beneficiaries into paid employment;

- the alleviation of hardship.

The social obligations requirement in the new s $1 \mathrm{~A}(\mathrm{~d})$ will be discussed below.

In view of the individual conceptualised at the heart of social security law, and in view also of the overriding purposes of the Social Security Act 1964, it is clear that all three aspects of law considered in Part II are certainly relevant in social security law.

\section{The Punishment of Bad Actions in Social Security Law}

The Act includes within it some limited provision for criminal penalty. Most charges laid pursuant to the Social Security Act 1964 will refer to s 127, where, in certain circumstances it is an offence for any person knowingly to make a false statement, or wilfully to do or say anything, or omit to do or say anything for the purpose of misleading or attempting to mislead any officer concerned in the administration of the 1964 Act "or any person whomsoever". These offences are slightly unusual in that they can be committed by omission, unlike most offences in the Crimes Act $1961 .{ }^{26}$ Imposing a penalty for this kind of offending points directly to the boundaries of good conduct for the social security recipient. Beneficiaries are expected to be in genuine need, and to be honest about their levels of eligibility for social security assistance.

\section{Positive Obligations and Sanctions in Social Security Law}

The Social Security Act 1964 also establishes a number of positive obligations. Indeed, from 1938 the notion that beneficiaries should discharge some degree of obligation in return for, or as a

25 Harlen v Ministry of Social Development [2012] NZHC 669, [2012] NZAR 491 at [40].

26 In the case of liable omissions under the Social Security Act 1964, the concomitant duty arises under s 12 which contains an obligation on applicants for benefits to answer all requests for information put by the chief executive. In addition, beneficiaries, under s 80A, must "forthwith" advise an officer of the Ministry of any change in circumstances pertaining to the right of the beneficiary to receive a benefit, or to the amount or rate of that benefit. 
response to, the provision of income support or assistance has always been present. William Parry, who held the social security portfolio from 1940-1949 emphasised, in a meeting with Māori leaders, the reciprocal obligation to work that accompanied entitlement to the unemployment benefit. ${ }^{27}$

By returning to the workforce when possible, welfare recipients were seen to have discharged their duties to maintain the labour force required for a cohesive society and economy, and the State, by applying such obligation, maintained a heavily targeted system, discharging its own duty to taxpayers to keep the system fiscally sustainable. Failure to observe the obligation to seek work meant that applicants failed the eligibility requirements and could not receive a benefit. ${ }^{28}$

Increasingly, since 1998, the State has included more obligations within the law. A tiered system of sanctions was also created for the breach of those obligations. ${ }^{29}$ Benefits can be cut, suspended, and even cancelled for the following breaches of positive obligations, among others:

- Failure by recipients of Jobseeker Support payments to comply with work test obligations, such as attending job interviews; ${ }^{30}$ and

- Failure for a parent in receipt of one of the main benefits to provide the name of the other parent of the child or children (which would enable that parent to be pursued for child support payments); ${ }^{31}$ and

- Failure by recipients of Supported Living payments to comply with work preparation exercises. $^{32}$

Of course, the imposition of positive obligations and sanctions for their breach potentially restricts the ability and right of beneficiaries to "choose a state of life freely". ${ }^{33}$ Such restriction ought, therefore, to be justified.

27 McClure, above n 17, at 117

28 Social Security Act 1938, ss 51(1)(a)-(e).

29 New work-testing obligations and sanctions were imposed by way of Social Security (Work Test) Amendment Act 1998, s 7

30 The obligation for a recipient of Jobseeker Support payments to attend job interviews is set out (with other work-testing requirements) at s 102A(c) of the Social Security Act 1964. The penalty for failure to observe this requirement is set out under s 117 .

31 The requirement to name the liable parent and the sanction for such failure is set out in Social Security Act 1964, s 70A(1)-(2). This obligation was introduced by way of the Social Security Amendment Act (No 2) Act 1990, s 18 .

32 The obligation to carry out such exercises appears at s 60Q and the sanction for failing to comply with such obligations is set out under s 117 .

33 Gaudium Et Spes, above n 1, at [26] 


\section{E Protection of Freedoms in Social Security Law}

In part of course, social security creates a level of freedom for people who would be otherwise in poverty to live with dignity having "everything necessary for leading a life truly human, such as food, clothing, and shelter; the right to choose a state of life freely". ${ }^{34}$ Positive legal duties create a higher level of conditionality for individuals to meet in order to attain or maintain eligibility for the receipt of that support. Extra conditionality can pose a grave threat to the freedom of beneficiaries to choose to act so as to seek fulfilment if the conditionality is not connected to the overall substantive purposes of the legislation. ${ }^{35}$ If positive duties are imposed, along with sanctions, which do not relate to the overriding purposes of the legislation any abrogation of freedom cannot fully be justified.

Positive obligations established by the Social Security Act 1964 have been, generally speaking, targeted and specific. Current work-testing obligations, originally enacted in 1998, and amended several times since then, impose many more restrictions on the actions of such recipients, and, since 2008, have been far more widely applied to qualifying recipients of Sole Parent Support, Supported Living payments, as well as Jobseeker Support. ${ }^{36}$ These added requirements have caused real questions about fairness in requiring such a broad range of beneficiaries to meet these obligations. Despite such concerns, some theoretical freedom at least remains to beneficiaries within the express provisions of the governing legislation. For example, work test obligations do not require income support recipients to undertake particular kinds of employment; such employment must only be suitable; otherwise the nature of the work was for the free individual to determine as best she could.

Of course to some degree this freedom becomes somewhat illusory in the face of everyday social security administration. The requirement that the employment be suitable sets a threshold; any such work must only satisfy the Chief Executive's determination of what is suitable, not the beneficiary's. ${ }^{37}$ This limitation presumably precludes Jobseeker Support recipients from turning down low-paid jobs, in favour of higher paid, or higher skilled work. Further, in reality labour market conditions can severely limit the kinds of jobs available, and being restricted to low wage

34 At [26].

35 Gráinne McKeever "Social Security as a Criminal Sanction" (2004) 26 Journal of Social Welfare and Family Law 1 at 10 .

36 Previously known as Domestic Purposes Benefit (Sole Carer), Sickness Benefit, and Unemployment Benefit.

37 The definition of "suitable employment" as set out in s3 of the Social Security Act 1964, in relation to a person, means "employment that the chief executive is satisfied is suitable for the person to undertake for a number of hours a week determined by the chief executive having regard to the employment required to satisfy the work test for that person." 
and low skill jobs can depress low paid workers' quality of life. ${ }^{38}$ However, even these narrow parameters are still relevant to the State's imperative to maintain a financially sustainable system of welfare, and can therefore be argued as justifiable. The direction given by the governing legislation upholds the freedom of the beneficiary as a general abstract principle to find whatever job she could, even while that freedom was undercut by the policy, administration and the realities of the labour market.

Even this abstracted principle of freedom has been stripped away from beneficiaries under the new social obligations imposed under the Social Security (Benefit Categories and Work Focus) Amendment Act 2013.

\section{SOCIAL OBLIGATIONS AND MORALS TESTING - IDENTIFYING THE "DESERVING POOR"}

The single most consistent value that has driven New Zealand social security policy and legislation from the earliest days of its provision in the 19th century has been that all individuals who can work, should. The primary questions in determining eligibility for social security support have been the extent of individual need and whether an individual could truly claim to be legitimately outside of the workforce. ${ }^{39}$ In view of the primacy of work as the driver of wellbeing in New Zealand social security legislation and policy the 2013 amendments mark something of a departure in the use of obligations within social security legislation.

The new social obligations now established in the legislation are not primarily aimed at ensuring individuals in receipt of benefit are able to work. Nor are they aimed primarily at restricting state expenditure on welfare, although both things can be seen as secondary drivers. Instead, these new obligations are aimed primarily at improving outcomes for children by making welfare recipients be better parents; a socially normative aim that has been beyond the purview of social security law before now.

\section{A Social Obligations under the Social Security (Benefit Categories and Work Focus) Amendment Act 2013}

These obligations are set out in ss 60RA-60RC of the Social Security Act 1964 . They apply to all non-youth beneficiaries with one or more dependent children in receipt of Jobseeker Support, Sole Parent Support, a Supported Living Payment, or an emergency benefit, including the spouse or partner of such beneficiaries. The new obligations require that qualifying beneficiaries:

38 See for example Roopali Johri Work values and the quality of employment: A literature review (Department of Labour, August 2005) at 23-24.

39 Michael Belgrave "Social Policy History: Forty Years on, Forty Years back" (paper presented to the Affording our Future Conference, Wellington, December 2012). 
- Take all reasonable steps to ensure that 3-5 year old dependent children are enrolled with and attending recognised early childhood providers, ${ }^{40}$

- Take all reasonable steps to ensure that all six-16 year olds are enrolled in, and attending school; ${ }^{41}$

- Take all reasonable steps to ensure that dependent children are enrolled with a primary health care provider; ${ }^{42}$ and

- Take all reasonable steps to ensure that dependent children are up to date with health checks required by the health providers (such as free Well Child/Tamariki Ora health checks provided to all New Zealand children from birth until five years). ${ }^{43}$

Failure to meet these obligations without sufficient explanation is subject to sanction under $\mathrm{s}$ 117 , including cutting or suspension of benefit. ${ }^{44}$

At one level it is possible to argue that these new social obligations, like work-testing, merely impose further conditionality upon applicants, raising the threshold and therefore diminishing the pool of potentially eligible applicants and ultimately, diminishing costs to government, consistent with the social security purpose of fiscal sustainability. However the end to which these measures are aimed comprises far more than increased conditionality. Sanctioning beneficiary parents with dependent children who do not enrol those children with the required Early Childhood provider (for example) does not meet an end relevant to determining eligibility for social security assistance on the basis of financial need. This new requirement does not enhance the ability of the relevant beneficiaries to prepare themselves adequately (in the case of sole carers) for re-entry into the workforce over and above the work-testing requirements already now imposed upon many beneficiaries with dependent children.

In short, this new conditionality is not relevant to the purposes for which social security was established and made available in the first place: relieving need in a financially sustainable manner (and, in New Zealand's case, returning to the workforce). Requiring a particular kind of care be provided for the dependent children of beneficiary parents imposes a norm for childrearing that substantially limits the freedoms of beneficiary parents to choose how to care for their own children. This normative expectation is expressly approved in the Explanatory note to the Bill: ${ }^{45}$

40 Section 60RA(3)(a)-(b).

41 Section 60RA(3)(c).

42 Section 60RA(3)(d).

43 Section 60RA(3)(e).

44 An exception to this is where a prosecution has been launched under s 24(1) of the Education Act 1989 (failure to enroll a child at a school or refusal to ensure that a child is enrolled at a school) or s 29(1) of the Education Act 1989 (which creates an offence and penalises irregular attendance at school).

45 Emphasis added. 
... the objectives of this Bill are to reform New Zealand's social security system so that it-

- reduces benefit dependency;

- is work focused, and expects and rewards independence;

- supports an investment approach that focuses resources where they will be most effective;

- is able to work with a greater number of beneficiaries to support them into work;

- reinforces social norms and improves social outcomes through the introduction of social obligations

for parents, and encouraging beneficiaries with warrants to arrest to clear them.

Social security law has supported particular social norms, for example, in providing assistance to sole parents to stay home to look after their children, and in asserting the value of employment as the central value around which the entire system operates. Nevertheless these new social obligations take such normative thinking a step further by requiring beneficiary parents to carry out parenting activities that other parents are not required to do (with the exception of school enrolment which is already legislatively required under the Education Act 1989). These requirements speak to a perceived standard of parenting, and are unconnected to either the need of those parents and children for social security assistance, or to the imperative upon the State to maintain a financially sustainable welfare system. This inconsistency with the usually understood purposes of the Social Security Act 1964 has been superficially addressed by the insertion of the new s 1A(d) into the Social Security Act $1964:^{46}$

s 1A The purpose of this Act is-

[(d) to impose, on the following specified people or young persons, the following specified requirements or obligations:

(iii) on people receiving certain financial support under this Act, social obligations relating to the education and primary health care of their dependent children.]

This provision has not yet been tested before the courts, but is curious. While part of a purposes provision, it does not refer to any purpose related to social security, unlike the earlier subsections. Instead, it merely asserts that one of the purposes of the Act is to impose social obligations upon people in receipt of certain kinds of financial support, with no reference to the end to which those social obligations would be employed. Neither is any insight offered in the Parliamentary debates or

46 This provision was inserted by the Social Security (Benefit Categories and Work Focus) Amendment Act 2013, s 5. See Part III, B of this article for the full text of this provision. 
the select committee as to the extent to which the new s 1A(d) aligned, or otherwise, with the existing provisions of s $1 \mathrm{~A}$. The Hon Paula Bennett merely stated: ${ }^{47}$

We are introducing social obligations to ensure that children in benefit-dependent homes get quality early childhood education, are enrolled with a doctor, and get their Well Child checks, and that schoolaged children are in school.

The purpose for the insertion of this provision becomes clear only by reference to materials external to the Parliamentary process. The final report of the Welfare Working Group in 2011 recommended the establishment of "parental obligations" with compulsory early childhood education and compulsory health checks. This recommendation referred to a need to improve outcomes for children in the welfare system. ${ }^{48}$

However laudable are the aims of improving outcomes for vulnerable children, it is clear these social obligations serve goals outside the usual scope and purposes of New Zealand social security. Further, in view of the fact that The White Paper on Vulnerable Children is to lead to the introduction of a Vulnerable Children's Bill in 2014, it appears that the notion of obligations for the parents of vulnerable children may well be highly relevant to such a legislative initiative, even as it is ultimately irrelevant to the purposes of social security legislation. ${ }^{49}$ The current legislation underpinning social security with its own purposes and scheme has clearly been used to facilitate the goals of another social initiative that is still in development.

These ill-placed social obligations have unsettled the balance that has been generally sustained in welfare law between pointing welfare recipients in the direction of the good, common life, and directing them in exactly how to live such a life, as defined by the State, to a degree not experienced by other citizens.

In the absence of any relevance of this new conditionality to the overriding purposes of social security law, it may well be possible to see social obligations as a modern, harsher, manifestation of morals testing as practised in earlier years of welfare provision in New Zealand.

\section{B Morals Testing - a Second Life}

With the advent of social obligations under ss 60RA-60RC beneficiary parents of dependent children, regardless of whether they are the parents of vulnerable children, are now themselves

47 (20 March 2013) 688 NZPD 8722.

48 See Recommendation 27, Welfare Working Group Long-Term Benefit Dependency: Recommendations (Welfare Working Group, February 2011) at 30. See also The White Paper for Vulnerable Children Volume 1 (Ministry of Social Development, Wellington, October 2012) at 25, also available online at $<$ www.childrensactionplan.govt.nz $>$.

49 The Vulnerable Children's Bill is being developed in 2013, and is to be introduced to Parliament by the end of 2014. See "Children's Action Plan" in The White Paper for Vulnerable Children, above n 48. 
vulnerable to a level of legislatively directed intrusion and direction that arguably outstrips that experienced by applicants undergoing morality testing under the Old Age Pension Act 1898 and the Social Security Act 1938. All such modern beneficiary parents of dependent children must be directed as to how they must raise their children to some degree. The fact that such direction is deemed necessary raises a presumption that those in receipt of a benefit require such direction, perhaps because of a presumed lack of capacity to make good decisions for their children. The opposite concern was at work behind the morality testing of the Old Age Pension Act 1898. Instead of restraining and curtailing the freedoms of pensioners, morality testing was deemed necessary to ensure such pensioners were marked out as dignified and respectable, so as to forestall any criticism of their receipt of public assistance.

\section{The Old Age Pension Act 1898}

The Act provided a small, means-tested pension for those residents over 65 who had resided in New Zealand for 25 years or more. This pension was funded from general taxation and represented the first major step by any New Zealand government in taking responsibility for the provision of a significant level of social security. Māori were included in the Act but often found themselves refused this means-tested pension, or granted a lesser amount, on the basis that a magistrate had determined they had some level of income or assets according to Native custom. ${ }^{50}$ Asians were excluded entirely. ${ }^{51}$ As with earlier legislative 19th century private benevolence, an obvious difference was often to be drawn between deserving and undeserving recipients. ${ }^{52}$

Express morals testing, as set out in the Old Age Pension Act 1898, was then deemed a necessary part of what was then a costly, and ultimately inefficient judicial process for the receipt of the pension. ${ }^{53}$ Applicants were expected to have their moral character tested before a stipendiary magistrate in open court as a part of the application process. ${ }^{54}$

Successful applicants must have led sober and reputable lives, not deserted their spouses, ${ }^{55}$ not been imprisoned for offences dishonouring them in the public estimation. ${ }^{56}$ It is important to note that the moral qualifications here do not form part of a set of on-going positive obligations on the successful applicant to behave in particular ways. Once applicants had proved their entitlement to

50 Old Age Pension Act 1898, s 66.

51 McClure, above n 17, at 19-20.

52 Tennant, above n 17.

53 Geoffrey Palmer "The Growing Irrelevance of the Civil Courts" (1985) 5 Windsor Yearbook of Access to Justice 327 at 339 .

54 Old Age Pension Act 1898, s 18.

55 Sections $8(5)$ and 66.

56 Sections $8(3), 8(4)$ and 66. 
the pension before the Magistrate, they were deemed to deserve the pension. ${ }^{57}$ To this extent there is a level of relevant connection between the morality testing and the purpose of the old age pension legislation. The purpose was stated in the following terms: ${ }^{58}$

WHEREAS it is equitable that deserving persons who during the prime of life have helped to bear the public burdens of the colony by the payment of taxes, and to open up its resources by their labour and skill, should receive from the colony a pension in their old age $[\ldots]$

The restrictive nature of the eligibility is clear, and in fact is worded in such a way that a successful applicant could be seen in a positive light, being someone who had, during their younger years "helped bear the public burdens of the colony". The status of pensioner was a dignified one, once the strict eligibility criteria were met. ${ }^{59}$ Some on-going requirement that the applicants be of good moral character remained but no direction given in the legislation on how this was to be achieved. In other words despite the highly restrictive, public application process for the pension, the moral qualifications did not, by dint of the legislation at least, impinge upon the pensioner's freedom to choose to live a life according to her own dictates. This freedom would enable her to choose to uphold the common good. Further, the moral purpose was expressly linked to the purpose of the legislation arguably providing justification for abrogation of freedom by way of the morals testing.

As social security became systematised and institutionalised with the advent of the Social Security Act 1938, the benefit application process was taken out of the judicial context and decisions about eligibility were carried out by government administration. ${ }^{60}$ Morality testing by the time of the 1938 Act was largely watered down to an eligibility requirement that applicants for each of the main benefits be of good moral character and sober habits, ${ }^{61}$ again, with no legislative directives on what specific behaviours comprised such characteristics. ${ }^{62}$

Morality testing in the provisions of social security legislation has not generally provided directives to individuals on how to live what might be determined to be a good life. Requiring applicants to be of good moral character and sober habits is arguably less restrictive of individual

57 Administrators of the pension may have made determinations about ongoing entitlement on the basis of morality, but not under authorisation from this provision.

58 Preamble.

59 McClure, above n 17, at 17.

60 Palmer, above n 53, at 340

61 See for example s 15(1)(e). Compare Old Age Pensions Act 1898, s 8(6).

62 Much could be said about the concepts of the "public morality" in legislation, that I lack the space to develop here. See for example Alan Cameron "Law Justice and the State" in Alan Cameron and Jonathan Boston Voices for Justice (Dunmore Press, Palmerston North, 1994) at 37-67 and Alan Cameron "'Dooyeweerd on law and morality: legal ethics - a test case"'(1998) 28 VUWLR 263. 
freedom than requiring all beneficiary parents to undertake Well Child checks within specific timeframes and enroll their children in approved Early Childhood centres when an autonomous individual in pursuit of the common good might choose to act a little differently.

\section{CONCLUSION}

This article opened with the definition of the common good as being the sum of those conditions of social life, which allow social groups and their individual members relatively thorough and ready access to their own fulfilment. The purposes of New Zealand social security law are consistent with this notion. In particular social security provides access to those conditions of social life to enable social security recipients to be free enough to live such a life. This access, however, can be conditional, requiring beneficiaries to undertake positive legislative obligations in order to receive that assistance. Requiring beneficiaries to act in certain ways can threaten the autonomy of such beneficiaries; and in particular their freedom to choose to live a good life. Such conditionality needs to be justified by way of a relevant connection to the purposes of the social security legislation. While fierce debate continues between the left and right over the appropriate extent of positive obligations such as worktesting, generally speaking positive obligations in the social security legislation can be said to relevant to the purposes of the Social Security Act 1964.

The social obligations introduced in 2013 are not relevant to the aims and objectives of social security legislation, being aimed mainly at child-welfare policy outcomes. In addition it appears the obligations are aimed at establishing a moral standard of behaviour - being a good parent - to which all beneficiary parents of dependent children are to be held. While morals testing has had a significant role in historic social security legislation in New Zealand the legislative tests, which applied such moral requirements do not appear to have been as directive as the modern social obligations provisions.

In the absence of a substantive connection between the social obligations and the purposes of the legislation there is little apparent justification for the abrogation of individual freedom these obligations impose.

The vision of the common good that does still reside at the heart of the social security system is undermined by the imposition of ill-placed social obligations. These obligations undercut the freedom of the individual at the heart of the social security system to choose to live the good life, even as the increased conditionality restricts access to the conditions necessary to be able to find that fulfilment. 
